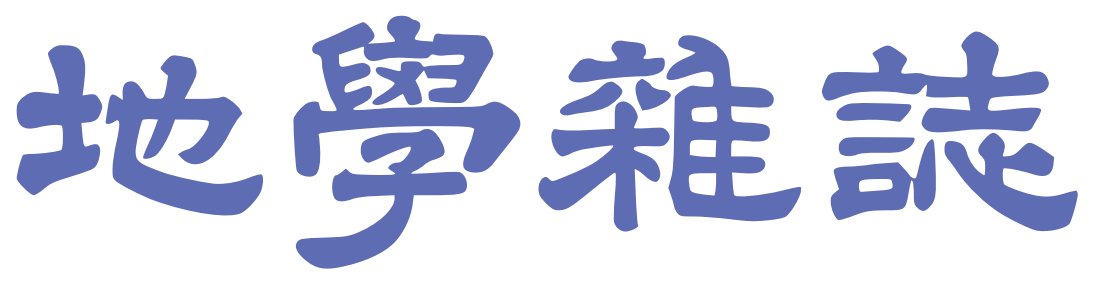

JOURMAL

OF

\section{GEOGRAPHY}

\section{東京地学協会}

TOKYO GEOGRAPHICAL SOCIETY

Founded in 1879

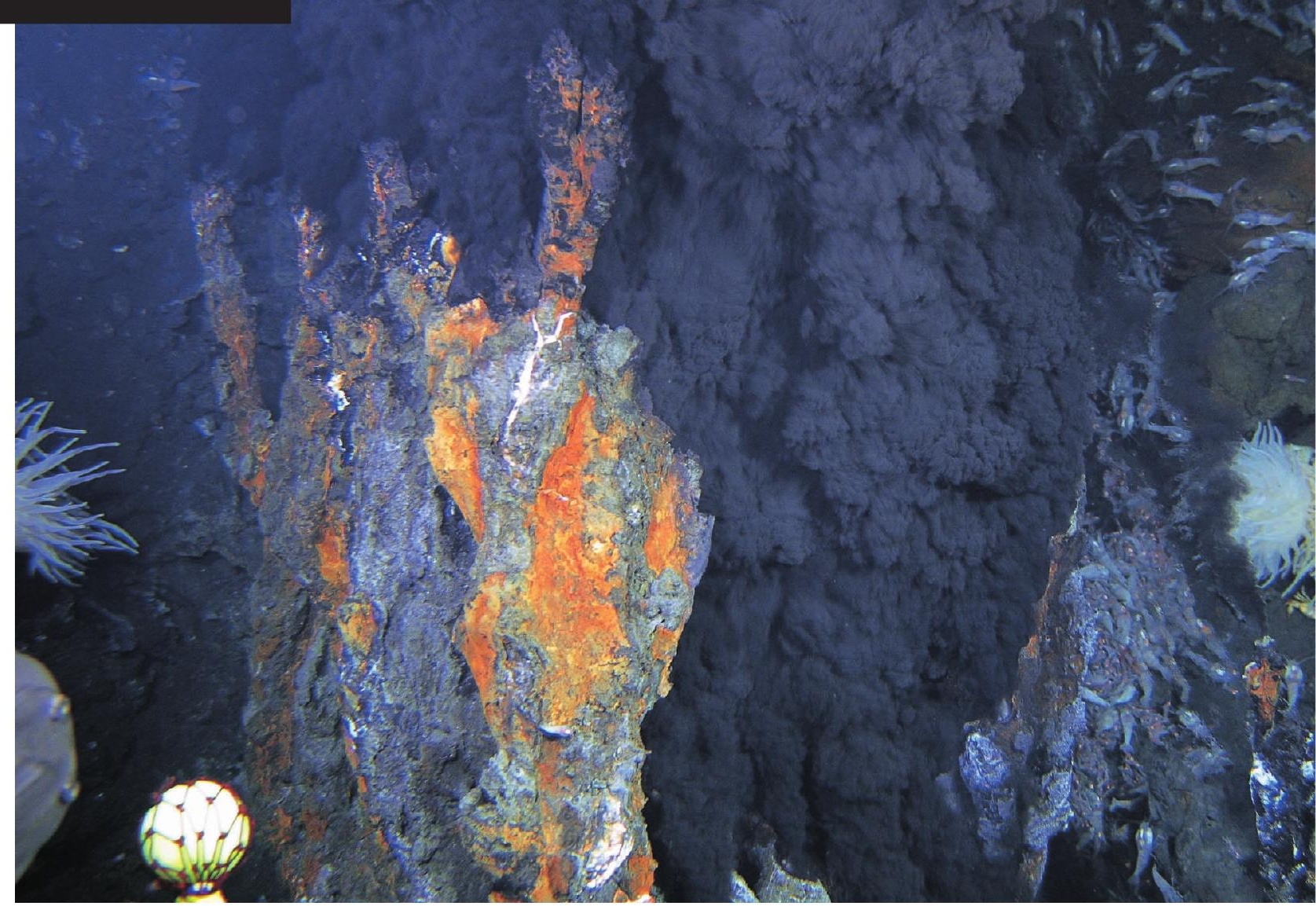

\title{
2009 VOL. 118
}

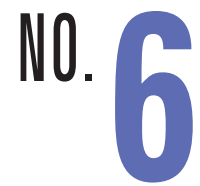

特集号: 海洋地殼内熱水循環と地下微生物圈の相互作用 Special Issue on "Hydrothermal Fluid Circulation Systems of the Oceanic Crust and Interactions among the Lithosphere, Hydrosphere, and Biosphere" 
標記の申請の受付をしますので, 希望者は所定の用紙により申請してください. 申請用紙は本協会事務局から取り寄 せるか，あるいは，本協会ホームページ（http：//wwwsoc.nii.ac.jp/tokyogeo/）からダウンロードしてお使いください. 締切りは平成 22 年 3 月 15 日（本協会事務局必着）です（詳しくは 1323 ページをご覧下さい）.

平成 21 年 12 月 25 日 社団法人 東京地学協会

\section{表紙写真}

\section{インド洋中央海嶺ロドリゲス三重点近傍で確認された ブラックスモーカー}

この写真はインド洋中央海嶺で行われた有人潜水船しんかい 6500 (海洋研究開発機構) の第659潜航（YK01-15航海）に扔いて撮影さ れた．ロドリゲス三重点の北方約 $30 \mathrm{~km}$ に位置する「かいれいフィー ルド」(南緯 $25^{\circ} 19.23^{\prime}$, 東経 $70^{\circ} 02.42^{\prime}$, 水深約 $2450 \mathrm{~m}$ ) は, インド 洋で初めて発見された熱水噴出域で, 熱水中の水素濃度が著しく高 いことが特徴である（Takai et al., 2004）。写真の熱水噴出孔は, カー リーチムニーと呼ばれるブラックスモーカーで, 噴出する熱水は $360^{\circ} \mathrm{C}$ を超える. 熱水が海水と混ざり黒色で細粒の金属硫化物を多量 に析出させている．写真左下に写っている網で覆われた球状の物体 は深海調查用の目印で, 直径は約 $5 \mathrm{~cm}$ である。この「かいれいフィー ルド」の熱水システム及びその熱水に依存した生態系の研究成果が, 「海底下の大河」モデル着想の大きなきっかけとなった.

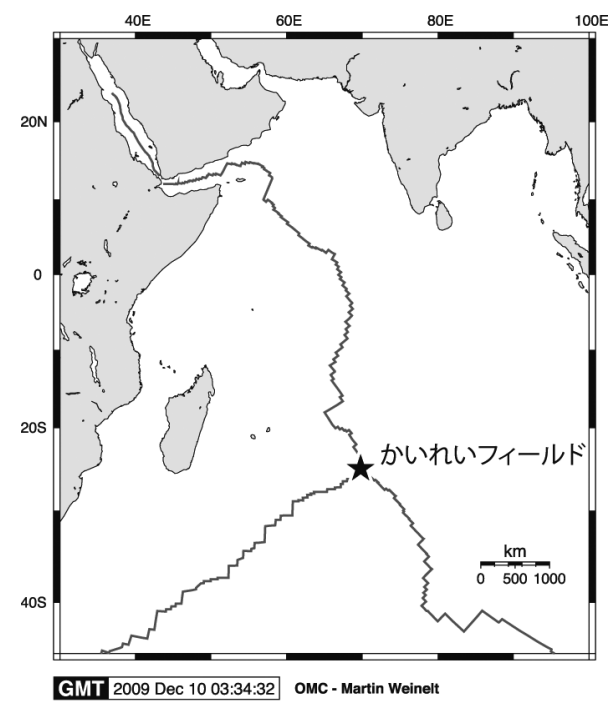

(解説：渡部裕美；写真提供：海洋研究開発機構 高井 研)

\section{Kali Chimney: A Vigorous Black Smoker in the Kairei Hydrothermal Vent Field, Central Indian Ridge}

This photograph was taken from the manned submersible Shinkai6500 during Dive 659 on the R/V Yokosuka cruise YK01-15 at the Kairei hydrothermal vent field (25 $19.23^{\prime} \mathrm{S}, 70^{\circ} 02.42^{\prime} \mathrm{E}, 2450 \mathrm{~m}$ water depth), about 15 miles north of Rodriguez Triple Junction, Central Indian Ridge. The Kairei field is the first witnessed active hydrothermal field in the Indian Ocean, and is known to host extraordinary $\mathrm{H}_{2}$-rich fluids (Takai et al., 2004). The Kali chimney is the main vent of the field with temperatures above $360^{\circ} \mathrm{C}$, accompanied by black particles of metal sulfide minerals precipitated by mixing with cold ambient seawater. A netting ball in lower left of this photograph is a part of a marker for deep-sea investigation, and the diameter of the ball is about $5 \mathrm{~cm}$. The multidisciplinary research on this hydrothermal field and associating ecosystem provided key insights for the TAIGA PROJECT.

(Explanation: Hiromi WATANABE; Photograph: Courtesy of Ken TAKAI, JAMSTEC)

\section{文献}

Takai, K., Gamo, T., Tsunogai, U., Nakayama, N., Hirayama, H., Nealson, K.H. and Horikoshi, K. (2004): Geochemical and microbiological evidence for a hydrogen-based, hyperthermophilic subsurface lithoautotrophic microbial ecosystem (HyperSLiME) beneath an active deep-sea hydrothermal field. Extremophiles, 8, 269-282, DOI 10.1007/s00792-004-0386-3. 